\title{
Ferrous Iron Oxidation by Acidithiobacillus ferrooxidans Immobilized on Refractory Clay Tiles
}

\author{
E.R. Donati* \\ Centro de Investigación y Desarrollo de Fermentaciones Industriales (CINDEFI, CONICET-UNLP), Facultad de Cien- \\ cias Exactas, Universidad Nacional de La Plata, 47 y 115 (1900) La Plata
}

\begin{abstract}
Refractory clay tiles are composed of kaolin, which is the commercial name of clay, and this consists mainly of kaolinite mineral. Two such tiles and caowool packed in glass columns were used for the immobilization of Acidithiobacillus ferrooxidans cells in a ferrous iron medium, which was percolated through the supports. Colonization was carried out by several media replacements with no further inoculation until maximum ferric iron productivity was reached. One of the tiles was discarded due to the high iron precipitation during bacterial growth. The columns with the other supports were used for ferrous iron oxidation in batch and continuous flow modes of operation and these appeared to be promising supports for A. ferrooxidans. A ferrous iron oxidation rate of $14.5 \mathrm{mmol} . \mathrm{l}^{-1} \mathrm{~h}^{-1}$ was reached in one of the columns in the continuous culture. After being used for several cultures, pieces of tiles with immobilized cells were stored at $4{ }^{\circ} \mathrm{C}$. Samples at different times were incubated in ferrous medium and these showed high cell activity even after 6 months.
\end{abstract}

\section{INTRODUCTION}

Acidithiobacillus ferrooxidans is a chemolithoautotrophic acidophilic bacterium that is of great importance in biohydrometallurgy [1]. This microorganism is involved in the bioleaching of metal sulfide ores essentially due to its iron(II) oxidizing capacity [2]. Metal sulfides are dissolved by the oxidizing action of iron(III), which is continually regenerated by the cells. Iron(III) production by bacterial action can also be employed in bioremediation processes [3-4].

The natural tendency of A. ferrooxidans to grow on surfaces, not only on inert supports but also on minerals, makes it a suitable microorganism for cell immobilization and it is also useful to increase iron(III) productivity [5-7]. Different immobilization methods and several supports have been employed, including glass beads, activated carbon particles, sand, polystyrene, polyurethane, poly(vinyl alcohol), calcium alginate, ion-exchange resin, nickel alloy fibre, PVC and diatomaceous earth [8-17]. A. ferrooxidans cells immobilized on supports can grow at higher dilution rates and reach high iron(III) productivity.

Reactors with attached A. ferrooxidans that continually produce iron(III) have been employed to enhance metal recovery from ores as well as in other applications [18-24]. In most cases, the conditions under which the immobilization process was performed led to abundant levels of jarosite [basic iron(III) sulfate] precipitation. This precipitation is usually described as an unwanted phenomenon due to the decrease in the rate of diffusion of reactants and products through the layer of deposits and also to the blockage ofpumps and valves. On the other hand, jarosite deposits par-

*Address correspondence to this autor at the Centro de Investigación y Desarrollo de Fermentaciones Industriales (CINDEFI, CONICET-UNLP), Facultad de Ciencias Exactas, Universidad Nacional de La Plata, 47 y 115 (1900) La Plata; Tel: +54 2214833794 - int. 113; Fax: +54 2214833794 int. 103; E-mail: donati@quimica.unlp.edu.ar ticipate in the biofilm formation process [25-27]. An interesting model proposed by Karamanev [27] describes the biofilm structure produced by $A$. ferrooxidans cells on the jarosite pores. Thus, support matrices with high porosity can be used to enhance jarosite precipitation and consequently the biofilm formation.

The main goal of the study described here was to assess the immobilization of $A$. ferrooxidans cells on highly porous refractory clay tiles (composed of kaolin). Iron(II) oxidation rates during the biofilm formation and the oxidative efficiency of this biofilm after storage at $4{ }^{\circ} \mathrm{C}$ were also evaluated.

\section{MATERIALS AND METHODS}

\section{Microorganism and Cultivation}

A strain of A. ferrooxidans from Santa Rosa de Arequipa (DSM11477) was used for these experiments. The microorganism was grown and maintained on $9 \mathrm{~K}$ medium [2] at $\mathrm{pH}$ of 1.80

\section{Support Matrices}

The supports used in this study were a ceramic fibre, the commercial name of which is caowool $\left(\mathrm{S}_{1}\right)$, and two refractory clay tiles $\left(S_{2}\right.$ and $\left.S_{3}\right)$. The compositions of the latter supports are as follows:

$\mathrm{S}_{2}: \mathrm{SiO}_{2}: 27.7 \%, \mathrm{Al}_{2} \mathrm{O}_{3}: 50.8 \%, \mathrm{Fe}_{2} \mathrm{O}_{3}: 0.38 \%, \mathrm{TiO}_{2}: 0.25 \%$, $\mathrm{CaO}: 17.1 \%, \mathrm{MgO}: 0.14 \%, \mathrm{Na}_{2} \mathrm{O}: 1.94 \%$ and $\mathrm{K}_{2} \mathrm{O}: 1.34 \%$.

$\mathrm{S}_{3}: \mathrm{SiO}_{2}: 54.7 \%, \mathrm{Al}_{2} \mathrm{O}_{3}: 42.8 \%, \mathrm{Fe}_{2} \mathrm{O}_{3}: 0.7 \%, \mathrm{TiO}_{2}: 1.7 \%$ and $\mathrm{CaO}: 0.6 \%$.

\section{Attachment to the Supports}

Each support (20 mg) was added to the bacterial suspension $(5.0 \mathrm{ml})$ previously filtered to remove jarosite. The test 
tubes were incubated at $30^{\circ} \mathrm{C}$ and $180 \mathrm{rpm}$ for $10 \mathrm{~min}$. The mixtures were then filtered through black ribbon filter paper and the number of cells remaining in suspension was determined by direct microscopic counting (see below in analytical procedures). Cell removal by the glass walls of the test tubes was determined in control tests in the absence of the supports. This value was taken into account when calculating the percentage of attachment to solids.

\section{Bacterial Growth in the Presence of the Support}

Cubic sections of each support $(3 \mathrm{~cm} \times 4 \mathrm{~cm} \times 3 \mathrm{~cm})$ corresponding to $7.5 \mathrm{~g}\left(\mathrm{~S}_{1}\right)$ or $13.4 \mathrm{~g}\left(\mathrm{~S}_{2}\right.$ or $\left.\mathrm{S}_{3}\right)$ were added to $250 \mathrm{ml}$ Erlenmeyer flasks containing $9 \mathrm{~K}$ medium $(100 \mathrm{ml})$ inoculated with $A$. ferrooxidans cells. The flasks were incubated at $30^{\circ} \mathrm{C}$ and $180 \mathrm{rpm}$. Sterile controls were performed by replacing the inoculum by an equal volume of sterile medium.

\section{Process of Biofilm Formation}

The reactor was a glass column $(30 \mathrm{~cm} \times 5 \mathrm{~cm})$. A piece of the support $(18 \mathrm{~cm} \times 4 \mathrm{~cm} \times 2 \mathrm{~cm} ; 50 \mathrm{~g})$ was suspended into the column. $250 \mathrm{ml}$ of $9 \mathrm{~K}$ medium (Jensen and Webb, 1995), initial $\mathrm{pH} 1.80$, previously inoculated with A. ferrooxidans cells was percolated through the column until the oxidation of iron was complete. An air flow of $1201 . \mathrm{h}^{-1}$ supplied the gaseous nutrients. When iron(II) was completely oxidized, the medium was replaced by fresh media without any additional inoculation. This procedure of consecutive batches allowed the formation of a biofilm. In continuous cultures the flow rates for fresh media were regulated with peristaltic pumps. These experiments were conducted in duplicate.

\section{Support Storage}

After the process of biofilm formation, pieces of the support with immobilized biomass were stored in the open air or in iron-lacking medium for 24 weeks. After 2, 12 and 24 weeks, samples of the support were placed in $250 \mathrm{ml}$ Erlenmeyer flasks with sterile $9 \mathrm{~K}$ medium $(100 \mathrm{ml})$ and maintained at $30^{\circ} \mathrm{C}$ in an orbital shaker at $180 \mathrm{rpm}$.

\section{Analytical Procedures}

Iron(II) concentrations were measured by titration with potassium permanganate. Total soluble iron was determined by atomic absorption spectrophotometry. Bacterial population in suspension was monitored using a Petroff-Haüsser camera in conjunction with a microscope with a phasecontrast attachment. Solid residues obtained during the experiments were analyzed by X-ray diffraction and Mössbauer spectroscopy.

\section{RESULTS AND DISCUSSION}

The percentages of attachment of $A$. ferrooxidans to the supports were $1.8 \%, 23.2 \%$ and $38.2 \%$ for $\mathrm{S}_{1}, \mathrm{~S}_{2}$ and $\mathrm{S}_{3}$, respectively. The level of adhesion is dependent on the physico-chemical properties of the bacteria and the solid surfaces and it is responsible for the first and reversible phase of biofilm formation. After that phase, an irreversible phase should be formed in order to build a suitable biofilm. In the case of A. ferrooxidans, the latter phenomenon is strongly associated with the precipitation of jarosite [25], which is also related to the initial bacterial adherence. A high bacterial attachment to the support would produce rapid iron(II) oxidation very close to the surface, thus increasing $\mathrm{pH}$ and iron(III) concentration and the subsequent iron(III) precipitation. These deposits on the surface would allow the subsequent adsorption of cells on the pores and the formation of the biofilm. Although the initial attachment is important, there are other factors that must be considered. One of those factors that has a positive effect on the biofilm formation is the tendency of some supports (due to their specific physicochemical characteristics) to increase jarosite precipitation on their surface regardless of the presence of attached bacteria. Once precipitation has occurred, cells can be adsorbed onto the surface of highly porous jarosite. However, the supports could inhibit the bacterial activity and consequently the biofilm formation. For these reasons, an experiment to study the bacterial growth in the presence of each support was carried out.

The results for the bacterial growth in the presence of each support are shown in Fig. (1). Although the supports did not affect the growth significantly, in the presence of support 2 the bacterial growth was slower than in the cultures with the other supports. Moreover, in this case the final $\mathrm{pH}$ value was the highest, which is consistent with the more basic characteristics of this support. The formation of iron(III) precipitates is highly dependent on $\mathrm{pH}$ as well as other factors such as ionic composition and concentration of the medium. It has been reported that $\mathrm{pH}$ values between 1.6 and 1.8 are appropriate to maintain high iron(II) oxidation rates and low levels of jarosite deposits [26]; at $\mathrm{pH}$ values above 2.0 the mass of jarosite increases with $\mathrm{pH}$, whereas values below 1.6 cause a decrease in the biooxidation rate probably due to inhibition by acidity [2] - and insufficient jarosite precipitation for the formation of a good biofilm [25]. In the case of support 2, the final $\mathrm{pH}$ was approximately 5 and, consequently, the amount of iron(III) precipitation was too high. Thus, a small amount of total iron remained soluble at the end of the bacterial growth. This

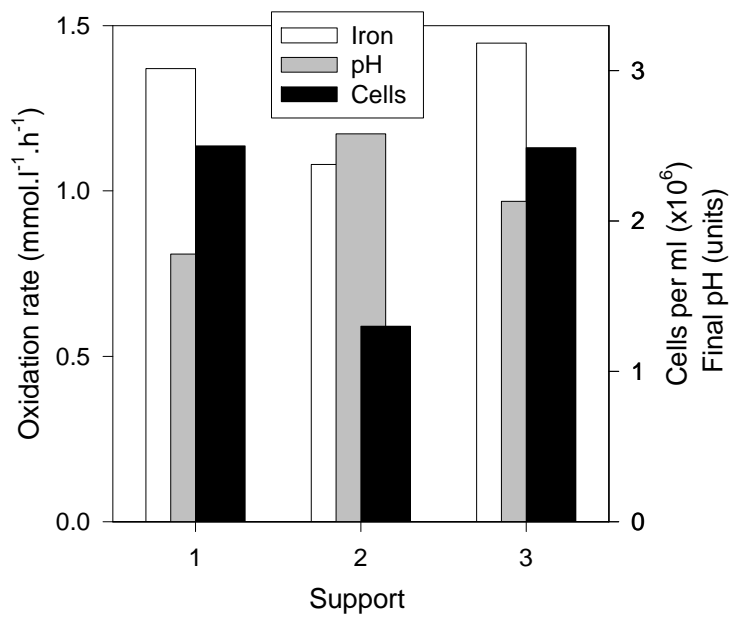

Fig. (1). Oxidation of iron(II) by A. ferrooxidans cells in the presence of different supports. White bars: oxidation rates. Grey bars: final $\mathrm{pH}$ values. Black bars: final bacterial population in suspension. Each data value represents the mean of the duplicates. Standard deviations for oxidation rates were less than $3 \%$ (5-10\% for cell populations). 
would be a serious disadvantage in biofim bioreactors because the purpose of such systems is to produce higher iron(III) concentrations; as a result, support 2 was ruled out for the subsequent experiments.

From a thermodynamic point of view, jarosite is the most stable iron(III) precipitate at the final redox and $\mathrm{pH}$ conditions in this kind of culture. However, the precipitation of this material is slow and requires several hours even after the complete oxidation of iron(II) [28]. For this reason, the supports were kept in contact with the spent medium for a further 12 hours in order to analyze the iron(III) deposits produced during the growth. Values of $55 \%, 97 \%$ and $78 \%$ of the total iron were precipitated in the cultures with supports 1, 2 and 3, respectively. These solids were characterized as potassium and ammonium jarosite by X-ray diffraction. However, analysis by Mössbauer spectroscopy proved the existence of one or more phases of ferric oxohydroxides (the exact composition of which was not determined) joined to jarosite. These precipitates can be less stable than jarosite but their formation is usually faster [28]. According to the Mössbauer results, the percentages of jarosite in the solid residues were $41 \%$ (for $S_{1}$ ) and $21 \%$ (for $S_{2}$ and $S_{3}$ ). The results for the consecutive batches run using the immobilized biomass on supports 1 and 3 with a rate between medium volume and mass support $(\mathrm{V} / \mathrm{m})$ of $5 \mathrm{ml} / \mathrm{g}$ are shown in Fig. (2). In the reactor with support 1 , the productivity values show a tendency to decrease. This behavior indicates that there is only a small immobilized biomass, which is even further removed by successive washing after each cycle. For this reason, this support was discarded after six cycles. When support 3 was employed a steady increase in iron(III) productivity was observed up to a maximum value (after 6 to 7 cycles). The constant value was probably reached because the new iron(III) deposits preclude nutrient access. However, the iron(III) productivity and the final soluble iron are not sufficiently high in comparison with values reported (5-50 mmol $\left.{ }^{1}-1 . h^{-1}\right)$ using other supports under similar, but not identical, conditions $[16,22,24]$.

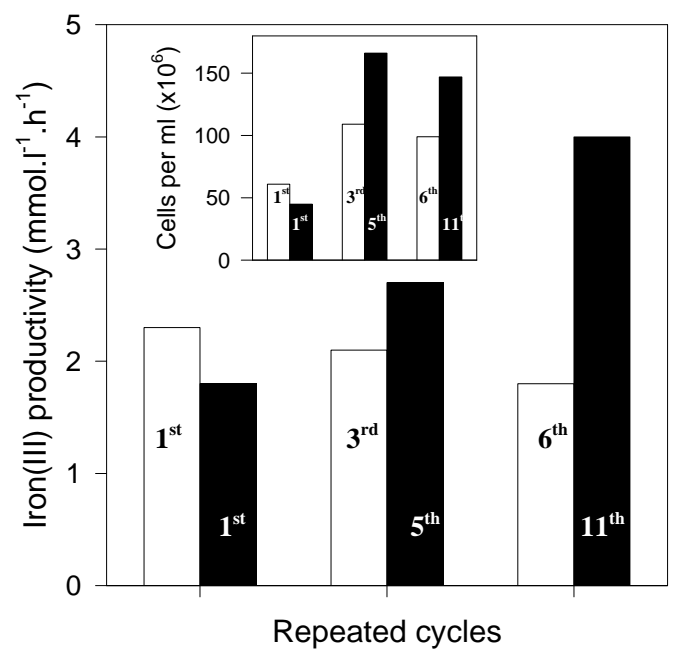

Fig. (2). Iron(III) productivity in bioreactors with immobilised biomass on supports 1 (white bars) and 3 (black bars) at $5 \mathrm{ml} / \mathrm{g}$ (volume/support mass). The values correspond to first $\left(1^{\text {st }}\right)$, third $\left(3^{\text {rd }}\right)$ and sixth $\left(6^{\text {th }}\right)$ cycle for support 1 and first $\left(1^{\text {st }}\right)$, fifth $\left(5^{\text {th }}\right)$ and eleventh $\left(11^{\text {th }}\right)$ for support 3 . Each data value represents the mean of the duplicates. Standard deviations for iron productivities were between $1-7 \%$ (5-12\% for cell populations).
When the reactor operating in repeated batch mode reached its highest iron(III) productivity, the culture medium was replaced by fresh media and a continuous flow of medium through a peristaltic pump was started. The $\mathrm{pH}$ value and iron(II) concentration in the inlet medium were 1.80 and 9 g. $1^{-1}$, respectively.

Iron(III) productivity as a function of the dilution rate is represented in Fig. (3). It can be seen that the immobilized cells have an advantage in a continuous operation, reaching higher productivity values than those obtained in the batch mode. The washout occurred at a higher dilution rate than in free cell reactors (about $0.11 \mathrm{~h}^{-1}$ ). It can also be seen that higher dilution rates lead to lower iron(III) precipitation levels.

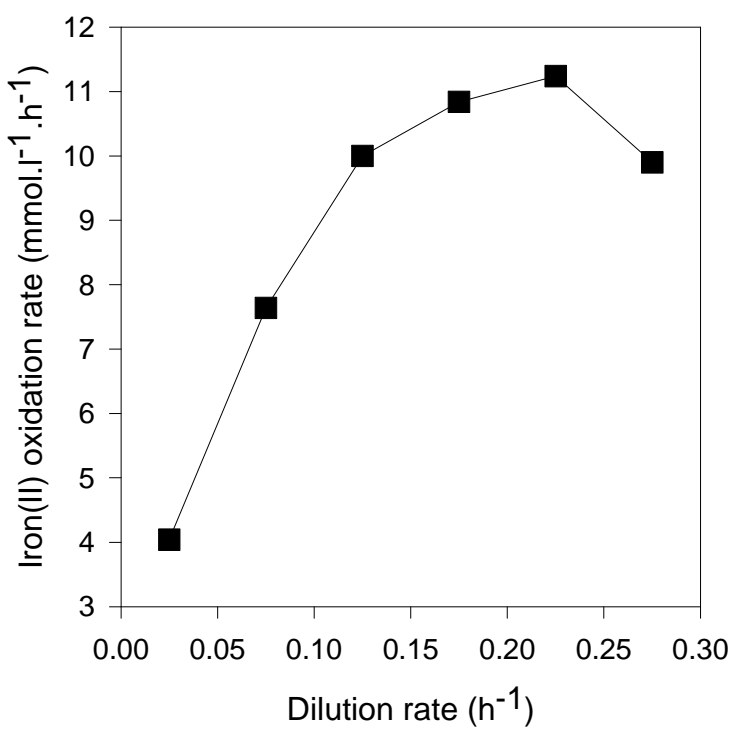

Fig. (3). Iron(III) productivity in the bioreactor with immobilised biomass on support 3 at different dilution rates. Each data value represents the mean of the duplicates. Standard deviations were less than $7 \%$.

In order to confirm this finding, new experiments in "batch mode" were carried out in which the rate $\mathrm{V} / \mathrm{m}$ mass was modified by reducing the support. As shown in Fig. (4), iron(III) productivity was significantly enhanced by increasing $\mathrm{V} / \mathrm{m}$ to $10 \mathrm{ml} / \mathrm{g}$. Higher values of $\mathrm{V} / \mathrm{m}$ did not give rise to improved performance and led to even worse results than the system with a $\mathrm{V} / \mathrm{m}$ of $5 \mathrm{ml} / \mathrm{g}$. The maximum iron(II) biooxidation rate of $14.5 \mathrm{mmol} . \mathrm{l}^{-1} \cdot \mathrm{h}^{-1}$ achieved for a V/m of $10 \mathrm{ml} / \mathrm{g}$ is comparable with most values reported in literature and is even higher than many. The specific value taking into account the mass of the support was 145 mmoles. ${ }^{-1} \cdot \mathrm{kg}^{-1}$ support mass; this value is higher than most reported for similar conditions; for example, in a recent report by Mousavi et al. [22], only 37 mmoles of iron(II). $\mathrm{h}^{-1} \cdot \mathrm{kg}^{-1}$ support mass were oxidized using low density polyethylene as a support. As expected, iron(III) precipitation was lower and this led to higher iron(III) concentrations at the end of each cycle. The iron(III) concentration in solution did not change even when the medium was kept in contact with the support for more than 24 hours after the iron(II) was exhausted. In a continuous mode of operation, similar behavior to that shown in Fig. (3) was obtained (data not shown).

One factor that must be taken in account in the industrial application of a reactor with immobilized biomass is its op- 
erational stability after the operation is stopped for long periods. The reactor should be stopped temporarily and restarted whenever required without further manipulation. This characteristic should be demonstrated not only when the support is maintained wet with nutrient-lacking medium but also when the medium is totally drained from the column. In order to analyze the possibility of reactivation, the support with immobilized biomass was placed in a medium with iron after being stored for 2 and 12 weeks. The results of the iron(II) oxidation assay are shown in Fig. (5). It was observed that the support stored in open air only shows suitable activity after 2 weeks. In contrast, the cells immobilized in the wet support were reactivated very rapidly after storage for 2 or 12 weeks. Finally, when the support was stored for 24 weeks, a long lag phase (7-15 days) was observed before cell reactivation.

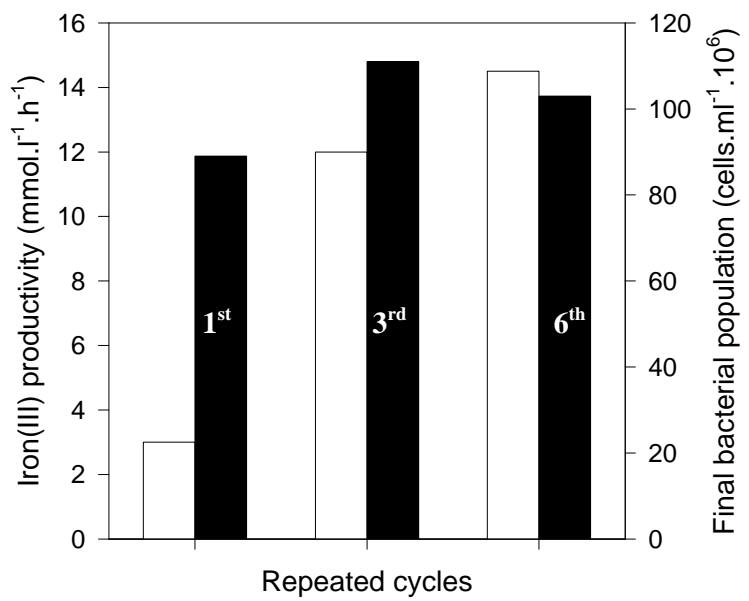

Fig. (4). Iron(III) productivity in the bioreactor with immobilised biomass on support 3 at $10 \mathrm{ml} / \mathrm{g}$ (volume/support mass). White bars: iron(III) productivity. Black bars: final bacterial population in the suspension. The values correspond to first, third and sixth cycle. Each data value represents the mean of the duplicates. Standard deviations were less than $5 \%$.

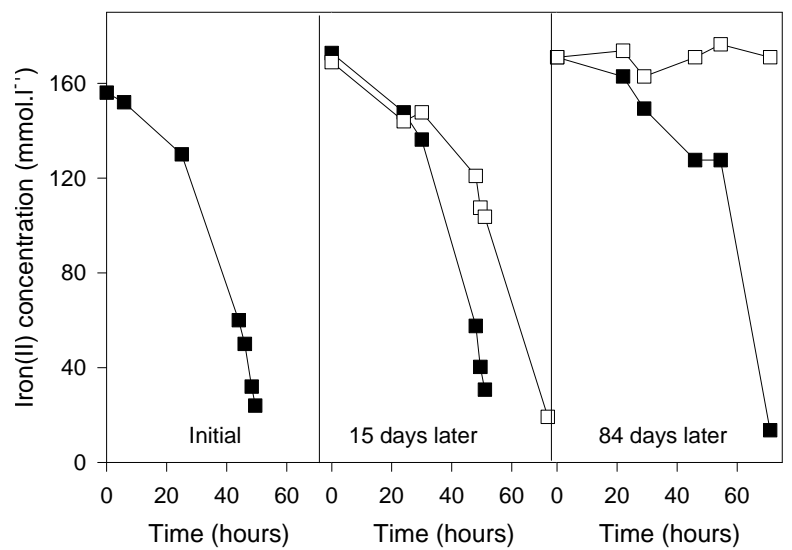

Fig. (5). Iron(II) oxidation by A. ferrooxidans cells immobilised on support 3 before storage (first graph) and after storage for 2 and 12 weeks (second and third graphs respectively) in open air $(\square)$ or in medium without iron $(\square)$ at $4{ }^{\circ} \mathrm{C}$. Each data value represents the mean of the duplicates. Standard deviations were between 9-15\%.

\section{CONCLUSION}

In summary, certain refractory kaolin tiles can be employed as appropriate supports for the immobilization of $A$. ferrooxidans cells and allow the generation of an optimal biofilm. One of the supports was better than the others probably because it presents an intermediate basicity enough to allow an initial jarosite precipitation and consequently the biofilm formation but not so high to leave low concentration of soluble ferric iron. The biofilm produced on the best support achieved high iron(III) productivity in both batch and continuous modes of operation, with lower levels of iron(III) precipitation at higher dilution rates. The immobilized biomass on the support clearly retained its oxidative efficiency during storage at $4{ }^{\circ} \mathrm{C}$ under dry or wet conditions for 2 or 24 weeks, respectively.

\section{ACKNOWLEDGEMENT}

This work was partially supported by ANPCyT (PICT 25300) and CONICET (PIP 5147).

\section{REFERENCES}

[1] Watling HR. The bioleaching of sulphide minerals with emphasis on copper sulphides — A review. Hydrometallurgy 2006; 84: 81108.

[2] Jensen AB, Webb C. Ferrous sulfate oxidation using Thiobacillus ferrooxidans: a review. Process Biochem 1995; 30: 225-36.

[3] Akcil A, Ciftci H, Deveci H. Role and contribution of pure and mixed cultures of mesophiles in bioleaching of a pyritic chalcopyrite concentrate. Miner Eng 2007; 20: 310-8.

[4] Rohwerder T, Gehrke T, Kinsler K, Sand W. Bioleaching review. Part A: progress in bioleaching: fundamentals and mechanisms of bacterial metal sulfide oxidation. Appl Microbiol Biotechnol 2003; 63: 239-48.

[5] Porro S, Ramírez S, Reche C, Curutchet G, Alonso S, Donati E. Bacterial attachment: its role in bioleaching processes. Process Biochem 1997; 32: 573-8.

[6] Karamanev DG, Nikolov LN. Influence of some physicochemical parameters on bacterial activity of biofilm: ferrous iron oxidation by Thiobacillus ferrooxidans. Biotechnol Bioeng 1988; 31: 295-9.

[7] Harneit K, Göksel A, Kock D, Klock J-H, Gehrke T, Sand W. Adhesion to metal sulphide surfaces by cells of Acidithiobacillus ferrooxidans, Acidithiobacillus thiooxidans and Leptospirillum ferrooxidans. Hydrometallurgy 2006; 83: 245-54.

[8] Armentia H, Webb C. Ferrous sulphate oxidation using Thiobacillus ferrooxidans cells immobilised in polyurethane foam support particles. Appl Microbiol Biotechnol 1992; 36: 697-700.

[9] Curutchet G, Donati E, Oliver C, Pogliani C, Viera MR. Development of Thiobacillus biofilm for metal recovery, in: Doyle RJ (Ed.), Microbial Growth in Biofilms, Part B: Special Environments and physicochemical aspects, Methods in Enzymology. Academic Press, San Diego, 2001; Vol. 337: pp. 171-186.

[10] Giaveno A, Lavalle L, Guibal E, Donati E. Biological ferrous sulfate oxidation by Acidithiobacillus ferrooxidans immobilized on chitosan beads. J Microbiol Meth 2008; 72: 227-34.

[11] Giro MEA, García Jr O, Zaiat M. Immobilized cells of Acidithiobacillus ferrooxidans in PVC strands and sulfite removal in a pilot-scale bioreactor. Biochem Eng J 2006; 28: 201-7.

[12] Gomez JM, Cantero D, Webb C. Immobilization of Thiobacillus ferrooxidans cells on nickel alloy fibre for ferrous sulphate oxidation. Appl Microbiol Biotechnol 2000; 54: 335-40.

[13] Long Z, Huang Y, Cai Z, Cong W, Ouyang F. Biooxidation of ferrous iron by immobilized Acidithiobacillus ferrooxidans in poly(vinyl alcohol) cryogel carriers. Biotechnol Lett 2003; 25: 245 9.

[14] Long Z, Huang Y, Cai Z, Cong W, Ouyang, F. Immobilization of Acidithiobacillus ferrooxidans by a PVA-boric acid method for ferrous sulphate oxidation. Process Biochem 2004; 39: 2129-33.

[15] Long Z, Huang, Y, Cai Z, Cong W, Ouyang F. Kinetics of continuous ferrous iron oxidation by Acidithiobacillus ferrooxidans immobilized in poly(vinyl alcohol) cryogel carriers. Hydrometallurgy 2004; 74: 181-7.

[16] Wakao N, Endo K, Mino K, Sakural Y, Shiota H. Immobilization of Thiobacillus ferrooxidans using various polymers as matrix. J Gen Appl Microbiol 1994; 40: 249-58. 
[17] Yujian W, Xiaojuan Y, Hongyu L, Wei T. Immobilization of Acidithiobacillus ferrooxidans with complex of PVA and sodium alginate. Polym Degrad Stabil 2006; 91: 2408-14.

[18] Grishin SI, Tuovinen OH. Fast kinetics of $\mathrm{Fe}^{2+}$ oxidation in packedbed reactors. Appl Environ Microbiol 1988; 54: 3092-100.

[19] Mazuelos A, Palencia I, Romero R, Rodriguez G, Carranza F. Design variables in high efficiency reactors for the biooxidation of ferrous iron in solution, in: Amils R, Ballester A. Eds., Biohydrometallurgy and the environment toward the mining of the $21^{\text {st }}$ century 1999; Elsevier, Amsterdam, pp. 501-510.

[20] Mesa MM, Andrades JA, Macías M, Cantero D. Biological oxidation of ferrous iron: study of bioreactor efficiency. J Chem Technol Biotechnol 2004; 79: 163-70.

[21] Mesa MM, Macías M, Cantero D. Mathematical model of the oxidation of ferrous iron by a biofilm of Thiobacillus ferrooxidans. Biotechnol Prog 2002; 18: 679-85.

[22] Mousavi SM, Yaghmaei S, Jafari A. Influence of process variables on biooxidation of ferrous sulphate by an indigenous Acidithioba- cillus ferrooxidans. Part II: Bioreactor experiments. Fuel 2007; 86: 993-9.

[23] Park D, Lee DS, Joung JY, Park JM. Comparison of different bioreactor systems for indirect $\mathrm{H}_{2} \mathrm{~S}$ removal using iron-oxidizing bacteria. Process Biochem 2005; 40: 1461-7.

[24] Porro S, Pogliani C, Donati E, Tedesco PH. Use of packed bed bioreactors. Application to ores bioleaching. Biotechnol Lett 1993; 15: 207-12

[25] Pogliani C, Donati E. Immobilization of Thiobacillus ferrooxidans: importance of jarosite precipitation. Process Biochem 2000; 35: 997-1004.

[26] Daoud J, Karamanev D. Formation of jarosite during Fe2+ oxidation by Acidithiobacillus ferrooxidans. Miner Eng 2006; 19: 960-7.

[27] Karamanev DG. Model of the biofilm structure of Thiobacillus ferrooxidans. J Biotechnol 1991; 20: 51-64.

[28] Dutrizac JE. The effectiveness of jarosite species for precipitating sodium jarosite. JOM 1999; 51: 30-2.

(C) E.R. Donati; Licensee Bentham Open.

This is an open access article distributed under the terms of the Creative Commons Attribution License (http://creativecommons.org/licenses/by/2.5/), which permits unrestrictive use, distribution, and reproduction in any medium, provided the original work is properly cited. 